\title{
Teachers perception on their readiness in integrating soft skills in the teaching and learning
}

\author{
Ilangko Subramaniam. Ph.D \\ ${ }^{I}$ (School of Languages, Literacies and Translation,Universiti Sains Malaysia, Malaysia)
}

\begin{abstract}
This study investigates the teachers readiness in integrating soft skills in the teaching and learning process in secondary schools. It also identifies the types of the soft skills that are more prevalent for the teaching and learning of the Malay language. The results show that teachers have the knowledge on soft skills and are aware of the pertinent role of the soft skills in the curriculum integration, yet they lack the practice of integrating the soft skills in teaching the language. This study gives an insight into the needs of the teachers to acquire the adequate knowledge and training in integrating the soft skills in language teaching.
\end{abstract}

Keywords : soft skill integration, teacher readiness, teaching and learning, language learning, Malay

\section{Introduction}

The Malaysian National Education Philosophy clearly states the intention in forging continuous efforts in developing the potential of individuals in a holistic and integrated manner with the aim of churning individuals who are intellectually, spiritually, emotionally and physically balanced. This intention aims at developing knowledgeable and competent students with high moral standards and sense of responsibility. The implementation of the Education Policy is succeeded in stages via the academic and co-curricular system in the schools. However, the academic system which is criticized for being exam-oriented needs to address the gaps of instilling soft skills as a manifestation to develop well-groomed students.

The low performance and lack of soft skills among the undergraduates in Malaysia has become a great concern and the higher learning institutions are blamed for failing to instill soft skills among the undergraduates. Nurturing soft skills however, is in reality a long process and needs to be developed from young with the guidance from parents - via teaching and learning activities, co-curricular activities as well as various programmes held in schools. The students' eleven years of schooling are considerably sufficient for these skills to be instilled. The soft skills so far instilled through the academia life however, needs to be instilled in a systematic and effective way through the assistance of educators as the main agents of intervention. The effectiveness of such intervention will depend highly on the comprehension of these skills by the teachers as well as on the strategy used in instilling the soft skills.

The term soft skills are defined in multiple perspectives by various scholars. A soft skill is a comprehensive concept which measures the ability and the capability of individuals and an organization's achievements [1]. A soft skill is also defined from the viewpoint of cognitive elements in the non-academic aspects such as positive values, leadership qualities, teamwork, communication skills as well as life-long learning [2]. These skills are linked with one's ability to complete specific tasks successfully and complementing personal traits, mental power, values, and self-image which portrays one's effectiveness and success in their career [3]; [4].

A more comprehensive definition is given in the context of corporate human capital management whereby soft skills are seen as traits that motivates effectiveness or excellent work performance [5]. Other scholars define soft skills as the internal characteristics or hidden traits which are related to effective work performance [6]. Such traits are only identified in specific work tasks. Thus, it is pertinent to note that soft skills correlates with measurable work performance according to acceptable standards. It is developmental; from early stage into higher stage as well as expert stage which can be diversified in various situations. Other definition encircles the presence of soft skills either in individual aspect, within a system or in a group [1]. These skills, according to Lepsinger [7], can be upgraded via training. In conclusion, the various definitions derived sums the presence of knowledge, skills and behaviour that affects one's work performance.

With such demands emplaced on soft skills, it is pertinent to suit the teaching and learning approaches to develop the students personal and interpersonal skills. Judith \& Tom [8] posit that it is important to expand knowledge based on model and theories by emphasising on the critical and analytical thinking skills. Such an emphasis will enrich the students to be better prepared for the workforce. In reality, however, this is the gap that needs to be addressed and there are calls for the higher learning institutions to review their curriculum which insofar, is more prescriptive and structured [9]. Employers on the other hand, laments the graduates over dependence on theory, principles and information that is less relevant for workplace literacies; particularly problem solving skills, decision making, team-work and communication skills [10]; [11]; [12]. As such, the 
burden falls on the employers to train these graduates in order to remain competitive in their workplace due to the graduates incompetence in self-confidence and social skills that are pertinent to the workforce. The acquired knowledge and skills from the universities are limited to their scope of study and poses as a mismatch to the real working world.

In the workforce, the graduates display limited ability on problem-solving skills, decision making skills as well as interpersonal skills. However, they need to be cognizant of the strategies to react to unprecedented demands [9]. These are some of the real life personal disorientations that graduates experience due to their inadequate preparation for the real workplace. Such disorientations also occur due to the perception that their work environment is a replication of what they have experienced in the learning environment whereby facilitation, instruction and guidance becomes the culture to be adhered to. The mismatch between reality and expectation, according to Candy \& Crebert[9] can be refined with self reflective learning so that the limitations of the prescriptive and stuructured learning can be minimized.

If the problem is not given serious consideration, then this presumably will leave an impact on the employers' anxiety over the lack of soft skills among graduates [13] ; [14]. In Britain, the government had initiated and consolidated a two-way interaction between the curriculum and the work sector since 1980s. The government affirms the higher learning institutions role by networking with the employers in aspects of skills training as well as internship for work-based learning experience acquisition.

In the context of Malaysia, the inadequacy of soft skills amongst graduates has posed a crisis to the human capital supply in the country. As such, the Malaysian Economic Planning Unit in the Prime Minister's department introduced the 1Malaysia Training Programme to assist graduates who remain unemployed upon graduation. The main aim of the programme is to instil competitiveness amongst graduate to succeed in the workforce. Although such short-term plans are beneficial for the graduates, yet a more practical and appropriate approach should begin at schooling years itself. This realization has allowed the Malaysian Education Ministry to begin the high performing schools to instil soft skills into their teaching and learning approach.

\section{Integrating soft skills in the teaching and learning activities}

Gregory, Kelly and Judith [15] posed a timely question of what is considered as knowledge. The polemic of this issue debated by the media, politicians, policy makers and researchers as well as discipline experts and academician lies on the fact that the basic concept lies on the basic skills, basic knowledge and competency that has educational value. There are also notions that knowledge encompass knowledge of value as well as knowledge of citizenship, national identity and others [15].

James[16] stressed the importance of civic knowledge, values, patriotism, environmental knowledge, critical thinking, decision making skillss, problem solving skills and other non-academic skills. His notion received many criticism but in the context of Malaysia, civic knowledge and nationhood are already implemented in the school curriculum direct and indirectly as the Ministry of Education (MoE) realises the needs in the education system to prepare students to compete in a globalised world. From the viewpoint of the school, soft skills complements students' academic excellence, successful employee and future undertakings (Management Division of Residential School and School of Excellence, Ministry of Education Malaysia, 2006). These skills are acquired through formal and non-formal teaching and learning activities, are transferable and applicable in various situations. The soft skills concept is closely related to the marketability of the students in the workforce; soft skills acquisition is expected to mould positive changes in students in their character building, control of feelings, self-motivation, ability to think critically and creatively, in interacting with others as well as the ability to work as a team (Management Division of Residential School and School of Excellence, Ministry of Education Malaysia, 2006).

The development and evaluation model of soft skills is further measured by integrating the soft skills indicators in the curricular, co-curricular activities and within the school environment. Evaluation is also based on the change in observerbal behaviour in the teaching and learning activities upon the integration of the soft skills. The evaluation per se is divided into two; evaluation by the teacher and self-evaluation. The teachers evaluate the students' achievement with the standard instrument available while self-assessment is done based on continuous reflections by the student. The students will subsequently receive certificates according to their level of achievement.

The integration of soft skills amongst students is highly dependent on the skills and competence of the teacher. The high knowledge level on content [17]; cognitive skills and decision making skills [18] are among other factors that contribute towards the effectiveness of the teaching and learning activities. Beijaard and Verloop[19] noted that practical knowledge in certain situation is also pertinent in determining the learning effectiveness amongst the students. Therefore, the views above summarize the fact that the effectiveness of integrating soft skills in the teaching and learning process is highly dependent on the readiness, comprehension and the knowledge of the teachers. 
In the context of educational conception, [20] posits that there are six main aspects that develop generic skills in students via the curriculum as well as the formal and informal activities in the higher learning institutions.This approach is applicable at the school level as it consolidates the students ability when they step into the higher learning institutions. Moreover, at the school level, remedial aspects, integration subject content, teaching process, engagement, remedial, integration and involvement are present in both formal and informal ways. As such, a careful and systematic planning will assist in reducing the competence conundrum at the higher learning institutions. The educator's conception on the transformation in acquiring soft skills that contrasts Barrie's(2007) notion.

\begin{tabular}{|c|c|c|c|c|}
\hline \multicolumn{3}{|c|}{$\begin{array}{l}\text { HOW GENERIC ATTRIBUTES ARE } \\
\text { DEVELOPED }\end{array}$} & \multirow[t]{2}{*}{ SUPPLEMENTARY } & \multirow{2}{*}{$\begin{array}{l}\text { INTEGRATED } \\
\text { 1. SUBJECT CONTENT: } \\
\text { Soft skills imparted in the subject } \\
\text { knowledge }\end{array}$} \\
\hline $\begin{array}{l}\mathbf{S} \\
\mathbf{T} \\
\mathbf{R} \\
\mathbf{U}\end{array}$ & \multirow{4}{*}{$\begin{array}{l}\text { Focus Teacher } \\
\text { and Teaching }\end{array}$} & $\begin{array}{l}\text { Subject } \\
\text { curriculum } \\
\text { content }\end{array}$ & & \\
\hline $\begin{array}{l}\mathbf{T} \\
\mathbf{U} \\
\mathbf{R} \\
\mathbf{A}\end{array}$ & & $\begin{array}{l}\text { Subject } \\
\text { curriculum } \\
\text { Process }\end{array}$ & & $\begin{array}{l}\text { 2. TEACHING PROCESS: } \\
\text { Soft skills imparted through the way the } \\
\text { subject knowledge is thought. }\end{array}$ \\
\hline $\begin{array}{l}\mathbf{I} \\
\mathbf{N} \\
\mathbf{T}\end{array}$ & & $\begin{array}{l}\text { Subject } \\
\text { Experience }\end{array}$ & & $\begin{array}{l}\text { 3. ENGAGEMENT: } \\
\text { Soft skills acquired when the students } \\
\text { engage with the subject's learning } \\
\text { experience. }\end{array}$ \\
\hline $\begin{array}{l}\mathbf{E} \\
\mathbf{R} \\
\mathbf{N} \\
\mathbf{A} \\
\mathbf{L}\end{array}$ & & $\begin{array}{l}\text { Non- Curriculum } \\
\text { Element }\end{array}$ & $\begin{array}{l}\text { 4. REMEDIAL: } \\
\text { Additional activities (lower level } \\
\text { approach) }\end{array}$ & \\
\hline $\begin{array}{l}\mathbf{A} \\
\mathbf{N} \\
\mathbf{D}\end{array}$ & \multirow[b]{2}{*}{$\begin{array}{l}\text { Focus Learner } \\
\text { and Learning }\end{array}$} & $\begin{array}{l}\text { Co-curricular } \\
\text { Process }\end{array}$ & $\begin{array}{l}\text { 5. INTEGRATION } \\
\text { Soft skills imparted via games, } \\
\text { societies and club activities } \\
\end{array}$ & \\
\hline $\begin{array}{l}\mathbf{E} \\
\mathbf{X} \\
\mathbf{T} \\
\mathbf{E} \\
\mathbf{R} \\
\mathbf{N} \\
\mathbf{A} \\
\mathbf{L}\end{array}$ & & $\begin{array}{l}\text { School } \\
\text { Experience }\end{array}$ & & $\begin{array}{l}\text { 6. INVOLVEMENT: } \\
\text { Soft skill is attained throughout } \\
\text { participation and involvement in school } \\
\text { activities }\end{array}$ \\
\hline
\end{tabular}

Figure 1:Eeducator's Conception on Methods of Instilling Soft Skills. (adapted from Barrie, 2007)

The integration of soft skills is achieved via formal and informal learning activities in school. Among the other channels that allow the integration of soft skills in learning include the teaching process, subject content, engagement, involvement, integration and remedial in the various formal and informal activities in the school (Fig 1). The acquisition of soft skills at the school level, thus can be developed further at the tertiary level. Omar [21] further stressed that the teaching and learning environment should emphasize on the needs of the workforce and the teachers should align the teaching and learning strategies in order to gauge students to acquire these soft skills.

The teachers' effective teaching capabilities are highly dependent on the diverse knowledge that the teachers possess. The teachers need to equip themselves with deep knowledge of his subject matter as this contributes to the competent use of the relevant discourses. This subsequently leaves a positive and significant impact on students' achievement [22]. It is pertinent to note also that knowledge is also highly dependent on pedagogical aspects such as teaching methodology, curriculum development, student management as well as knowledge on soft skills. In other words, soft skills cannot be considered an isolated element; it is dependent on pedagogy also.

There are various teaching methodology that are dependent on the students' background, the type of knowledge integrated, the teachers' ability and competence as well as the school environment. As such, the teachers too need to acquire the soft skills, particularly the organisational skills, communication skills, subject content presentational skills, questioning and getting feedback as well as evaluating skills. Eggen and Kauchak [23] have stressed the importance of interaction and integration skills which are very pertinent in the teaching and learning process. The awareness of the importance in soft skills as such has increased the need to study the soft skills acquisition amongst teachers too. In Britain and several other countries, soft skills evaluation among 
teachers are given serious considerations and adopted as a policy implementation of the school authorities. Laws are also enacted to ensure the professionals; particularly educators must meet the competence level required as well as the soft skills that are integrated in the evaluation [1].

Although various views on teaching have highlighted on competence and teacher's skills, yet it is noted that little elaboration is given to the definition of effective and good teaching. A good teaching method should be holistic whereby the teachers' attitude, knowledge, behaviour, thoughts and decision making skills are given due considerations. Erik \& Piet [1] developed the competency model to evaluate the teachers' competence. According to Erik \& Piet [1], a teacher's competence begins with his effect of the planning of learning activities. The effect of the planning involves the learning environment as well as cordial relationship with the parents and the students. The subsequent competence that pursues is the action component whereby instructions, feedback and teamwork spirit are instilled. Preceding this is the decision making skills in which decisions are made for long-term needs, immediate needs or within the classroom setting needs. However, the decision making stage, should be based on fair and professional judgments.

In view of the current transformation and needs, the MoE has stipulated the achievements that must be met after serious considerations taken in the political, economy and social needs of the nation. The teachers are trained with various skills and knowledge in line with the National Education Policy as well as the National Education Philosophy. The teachers need to know curriculum content, the teaching and learning process as well as the short-term and long-term education philosophy. The pedagogical aspects on the other hand should be give serious consideration to the students' multiple learning method in order to cater to the real needs of the students. This needs are pertinent to assure a balanced development amongst the multiracial, cultural and multi religion citizentry as in Malaysia. Only then the education system will succeed in churning out students who are knowledgable, skillful as well as balanced mentally, emotionally and physically. Hence, such an aspiration can only be realized with the comprehension and dedicated involvement of the teachers in bringing about such dynamic educational reform.

\section{Methodology}

This study employed a quantitative approach to identify teachers' knowledge level of soft skills and the variety of soft skills emphasized in the teaching and learning of the Malay language and to determine the level of soft skills acquisition among the Malay language students through questionnaires. The items included questions based on soft skills understanding, types of soft skills understanding, the need for soft skills and method of instilling soft skills in the teaching and learning process. The teachers were interviewed to obtain information on the method employed to instill soft skills amongst students.

The sample consists of secondary school Malay language teachers from the North-east district and South-west district of the Penang state in Malaysia. A total of 44 schools were selected; of which 23 schools were based on random selection. For the schools which were randomly selected, the Principal and Senior Assistance of the school assisted in distributing the questionnaires. A total of 200 respondents participated in this study ranging from 3 respondents to 13 respondents depending on the population of the school. The respondents were the Malay language teachers who teach in the Remove Classes to the Form 5 level. However, the option to indicate the respondents' background as Malay teachers or non-Malay teachers was not included as a requirement in this study.

The research instrument is divided into three sections. In the first section, there were 25 items on the Malay language teachers' comprehension of soft skills according to four specific domains; mainly the knowledge, application, preparation and the acquisition (Table 1).

\begin{tabular}{lc} 
Table1: The domains and numbers of soft skills item specification \\
\hline Domains & No. of Items \\
\hline Knowledge & 5 \\
Application & 8 \\
Preparedness & 5 \\
Acquisition & 7 \\
& \\
\multicolumn{1}{c}{ Total } & $\mathbf{2 5}$ \\
\hline
\end{tabular}

The second part of the instrument aims at eliciting information on the various soft skills imparted via the Malay language teaching and learning activities. A total of ten soft skills were identified to obtain the necessary data. The final section in the instrument consists of 11 soft skills items to identify the soft skills acquision by the students. All these skills are part of the 13 soft skills proposed for the High Performing Schools in the Ministry of Education. These include communication skills, problem solving skills, critical thinking skills, 
creative thinking, decision making skills, team work, interpersonal, life long learning, presentational skills, entrepreneurship and environmental awareness.

Several expert reviews were done by five experienced heads from the High Performing Schools, controlled schools and normal schools in Penang, with three other Malay language "Excellent teachers". The instrument was further refined with the feedback from these personnels. Questions with high emphasis on the teacher's knowledge of soft skills were deemed unnecessary as the study required only basic comprehension level of soft skills. Moreover, the integration of soft skills at school level is considerably a new initiative; as such school heads, lecturers as well as the Malay language teachers feedback to simplify the questionnaire was taken into consideration. A pre-test was carried out to measure all the 25 items based on Cronbach's Alpha coefficient value. Cronbach's Alpha reliability shows a high value score at 0.855 for five different items that measures the teachers knowledge on soft skills. A high Cronbach's Alpha of 0.875 score is also present in the application domain in the eight items of teaching and learning of the Malay Language. As for the five items in the teacher's preparation domain, the Cronbach's Alpha value is 0.812 while the seven items soft skills acquisition domains scored a 0.810 score. On average, all the 25 items tested showed a high reliability with a Cronbach's Alpha score of 0.893. Cronbach's Alpha reliability value for the 11 focused soft skills in the Malay language teaching shows a high score of 0.929 . The soft skills acquisition among students also displayed a high reliability value of 0.956 Cronbach's Alpha value for 11 items.

A 5-point Likert scale, ranging from "do not agree at all to agree fully', was used to measure the teachers' comprehension level. The comprehension level values ranged from 1.00 to 5.00. Question two on "What are the soft skills emphasised by the teacher in the teaching and learning of the Malay Language?" a total of 11 elements of soft skills were identified. The elements are: communication skills, problem solving skills, critical thinking skills, creative thinking, decision making skills, team work, interpersonal, life long learning, presentational skills, entrepreneurship and environmental awareness. For this question too, the likert scale and the same specification were used as in the earlier question.

For question 3; "What is the soft skills level that is acquired in the Malay Language subject?" A total of 11 soft skills were identified - communication skills, problem solving skills, critical thinking skills, creative thinking, decision making skills, team work, interpersonal, life long learning, presentational skill, entrepreneurship and environmental awareness. The 5-range likert scale was also used for this question with a knowledge acquisition value ranging from 1.00 to 5.00 .

The data was analyzed using Statistical Packages for the Social Sciences (SPSS) version 19.0 application to identify the data descriptively for mean, frequency and percentage. The findings for research question 1 is based on mean score on the scale of very high comprehension, high comprehension, moderate, low and very low comprehension level. This is depicted in the Table 3.9 below;

The data is analyzed based on the research questions posed as below:

1. Do the Malay Language teachers have the knowledge of soft skills?

2. Which element of soft skill is given emphasis in the teaching of Malay Language?

3. What is the level of soft skill acquisition of the students who are taking up the Malay language?

The data showed that the majority of the respondents in this study were females. There were 22.0 percent $(n=44)$ male respondents and 78.0 percent $(n=156)$ female respondents. A total of 112 (56.0 percent) respondents were teachers with specialisation in Malay Language studies from the universities and teacher training colleges. The remaining 43.5 percent $(n=87)$ respondents consist of non-Malay option teachers.

\subsection{Research Question 1:}

\section{Results}

\section{Do the Malay Language Teachers Have the Comprehension of Soft Skills?}

The result shows that the teachers have high comprehension level of soft skills. For the total of 25 question items, the mean is 4.1; a depiction of high understanding level of soft skills among the respondents. The knowledge and acquisition domains are also high with a mean of 4.4 for 5 -item and mean 4.3 for the 7 -item question. The application and the teachers preparedness also showed a high level with a mean of 4.1 and 3.6 respectively (Table 4) 
Table 4: Mean and Level of Soft Skills Comprehension Domain

\begin{tabular}{lccc}
\hline Domains & No. of Item & Mean & Level \\
\hline & 5 & 4.4 & Very High \\
Knowledge & 8 & 4.1 & High \\
Application & 5 & 3.6 & High \\
Preparedness & 7 & 4.3 & Very High \\
Acquisition & & & High \\
Total & $\mathbf{2 5}$ & $\mathbf{4 . 1}$ & \\
\hline
\end{tabular}

The overall knowledge of the teachers were high with a score of mean value of 4.4. This shows the teachers high level of basic knowledge on soft skills based on the five items given. All the items depict a high level with the highest score at 4.6 for item 1(Skills other than academic skills) and 29 (Its important to be applied in teaching). Item 4 (Soft skills enhances self-confidence) scored a high mean level of 4.5 while item 3 (Wide open job opportunities) and 24 (Improve academic achievement) showed a mean score of 4.2 and 4.1 respectively; a high level of mean score (Table 5).

Table 5: Mean and Level of Soft Skills' Knowledge

\begin{tabular}{|lccc|}
\hline \multicolumn{1}{|c}{ Knowledge Domains } & Item & Mean & Level \\
\hline Skills other than academic skills & 1 & 4.6 & Very High \\
Its important to applied in teaching \& & & & \\
learning & 2 & 4.6 & Very High \\
Wide open job opportunities & 3 & 4.2 & High \\
Increase self-confidence & 4 & 4.5 & Very High \\
Improve academic achievement & 24 & 4.1 & High \\
Total & $\mathbf{5}$ & $\mathbf{4 . 4}$ & Very High \\
\hline
\end{tabular}

The application of soft skills as shown on item 8 recorded a mean value of 4.1(Table 6 ). Item 6 on the need for introducing soft skills in Malay language teaching recorded the highest mean of 4.4 while item 20 (Engage students in learning activities) and 21 (Interesting language learning activities) depicted a same high value of 4.3. The other items that recorded high means are 5 (Malay Language curriculum objectives), 7 (Need specific learning activities), 9 (Will not disrupt teaching and learning activities), 10 (Will not disrupt students preparation) and 25 (Implemented in a planned and systematical way).

Table 6: Mean and Level of Soft Skills' Application

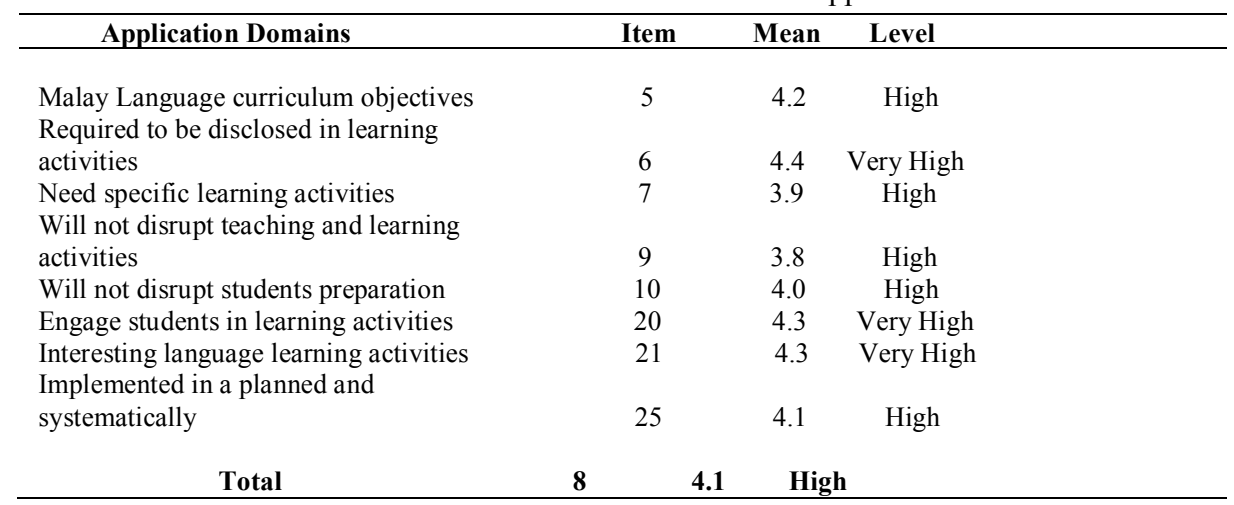

The overall domain on preparedness also listed a high mean value of 3.6. The highest being Item 18 ( I often integrate soft skill ) compared to the 5 items tested with a mean of 4.0. While all other items in the various domains scored highly with a range of 3.7 to 3.9, item 8 (instilling soft skill is burdensome) however, scored a low mean value of 2.4 (Table 7 ).

Table 7: Mean and Level of Soft Skills’ Preparedness 


\begin{tabular}{lccc}
\hline Preparedness Domains & Item & Mean & Level \\
\hline & & & \\
Burdensome application of soft skills & 8 & 2.4 & Low \\
I have a knowledge & 16 & 3.9 & High \\
I have the skills and abilities & 17 & 3.8 & High \\
I always apply & 18 & 4.0 & High \\
I need training/courses & 19 & 3.7 & High \\
$\quad$ Total & $\mathbf{5}$ & $\mathbf{3 . 6}$ & High \\
\hline
\end{tabular}

The analysis on the teachers perception on soft skills acquisition in the Malay language according to the 7-item questions shows a high score with an average mean of 4.3 (Table 8). Item 11(Communication skills are very important), 12(Communication skills can be applied), 13(Presentation activities increase), 15(Critical skills essential) and 23 (Group work carried out during the learning) recorded a high score between 4.3 to 4.4. The lowest record in this domain was item 14 (Have mastered the skills of presentation) with a score of 3.8.

Table 8: Mean and Level of Soft Skills'Acquisition

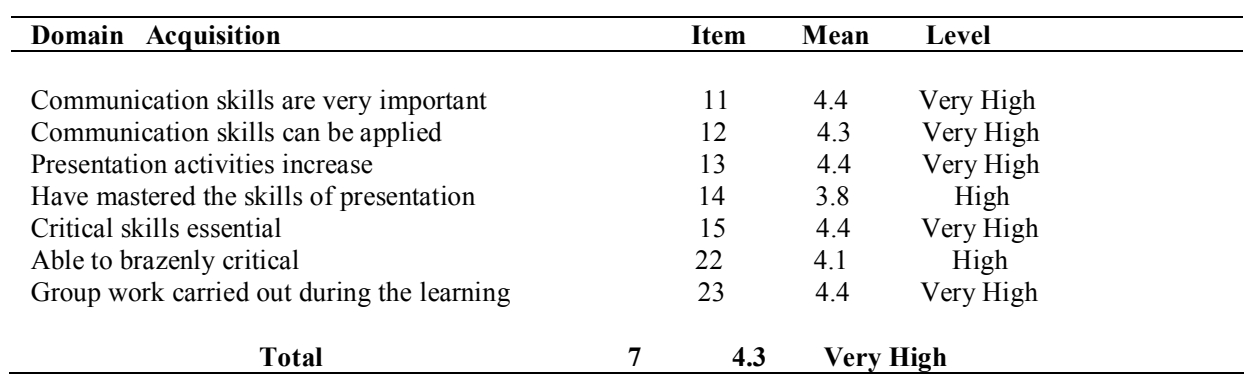

\subsection{Research Question 2:}

\section{Which Element of Soft Skills is Given Emphasis in the Teaching of Malay Language?}

The analysis shows that communication skill is emphasized highly in the teaching and learning of the Malay Language (Table 9). The communication skill depicts high level of mean score $(m=4.48)$. This is followed by team work $(m=4.38)$, entrepreneurship skill $(m=3.17)$, environmental consciousness $(m=4.13)$ and problem solving skill $(m=4.17)$. Other skills with very high score include interpersonal skill $(m=4.35)$, creative thinking $(m=4.31)$, critical thinking $(m=4.30)$, life long learning $(m=4.27)$, decision making skills $(m=4.24)$ and presentation technique $(m=4.23)$. The overall analysis shows that the soft skills are emphasized in the Malay Language teaching and learning process with a high mean value of 4.24 . 
Table 9: Frequency Distribution, Percentage, Mean and Level of Soft Skills Emphasis

\begin{tabular}{|c|c|c|c|c|c|c|c|c|}
\hline Item & 1 & & 2 & 3 & 4 & 5 & Mean & Level \\
\hline \multirow[t]{2}{*}{ Communication } & [1] & {$[0]$} & [3] & [98] & [100] & $\begin{array}{ll}4.48 \\
\end{array}$ & Very High & \\
\hline & $0.5 \%$ & $0 \%$ & $1.5 \%$ & $49.0 \%$ & $50.0 \%$ & & & \\
\hline \multirow[t]{2}{*}{ Team Work } & [1] & {$[0]$} & [1] & [113] & [82] & 4.38 & Very High & \\
\hline & $0.5 \%$ & $0 \%$ & $0.5 \%$ & $56.5 \%$ & $41.5 \%$ & & & \\
\hline \multirow[t]{2}{*}{ Interpersonal } & [1] & {$[0]$} & [9] & [108] & [82] & 4.35 & Very High & \\
\hline & $0.5 \%$ & $0 \%$ & $4.5 \%$ & $54.0 \%$ & $41.0 \%$ & & & \\
\hline \multirow[t]{2}{*}{ Creative Thinking } & [1] & {$[0]$} & [14] & [105] & [80] & 4.31 & Very High & \\
\hline & $0.5 \%$ & $0 \%$ & $7.0 \%$ & $52.5 \%$ & $40.0 \%$ & & & \\
\hline \multirow[t]{2}{*}{ Critical Thinking } & [1] & {$[0]$} & [14] & [108] & [77] & 4.30 & Very High & \\
\hline & $0.5 \%$ & $0 \%$ & $7.0 \%$ & $54.0 \%$ & $38.5 \%$ & & & \\
\hline \multirow[t]{2}{*}{ Lifelong Learning } & [1] & [1] & [17] & [104] & [77] & 4.27 & Very High & \\
\hline & $0.5 \%$ & $0.5 \%$ & $8.5 \%$ & $52.0 \%$ & $38.5 \%$ & & & \\
\hline \multirow[t]{2}{*}{ Decision Making } & [1] & [1] & [7] & [131] & [60] & 4.24 & Very High & \\
\hline & $0.5 \%$ & $0.5 \%$ & $3.5 \%$ & $65.5 \%$ & $30.0 \%$ & & & \\
\hline \multirow[t]{2}{*}{ Presentation } & {$[1]$} & [2] & [11] & [123] & [63] & 4.23 & Very High & \\
\hline & $0.5 \%$ & $10.0 \%$ & $5.5 \%$ & $61.5 \%$ & $31.5 \%$ & & & \\
\hline \multirow[t]{2}{*}{ Problem Solving } & {$[1]$} & {$[2]$} & [17] & [122] & [58] & 4.17 & High & \\
\hline & $0.5 \%$ & $1.0 \%$ & $8.5 \%$ & $61.0 \%$ & $29.0 \%$ & & & \\
\hline \multirow[t]{2}{*}{ Sensitivity In Environment } & [1] & [1] & [21] & [124] & [53] & 4.13 & High & \\
\hline & $0.5 \%$ & $0.5 \%$ & $10.5 \%$ & $62.0 \%$ & $26.5 \%$ & & & \\
\hline \multirow[t]{3}{*}{ Entrepreneurship } & {$[3]$} & {$[7]$} & [49] & [113] & {$[28]$} & 3.78 & High & \\
\hline & $1.5 \%$ & $3.5 \%$ & $24.5 \%$ & $56.5 \%$ & $14.0 \%$ & & & \\
\hline & \multicolumn{5}{|c|}{ Total } & Mean & 4.24 & Very High \\
\hline
\end{tabular}

*indication : $1=$ =strongly disagree; $2=$ disagree; $3=$ uncertain; 4=agree; $5=$ strongly agree scaling preference of soft skills in teaching and learning of the Malay language mean $1.00-1.80$ : level - very low mean $1.81-2.60$ : level - low rendah mean $2.61-3.40$ : level - moderate mean $3.41-4.20$ : level - high mean $4.21-5.00$ : level - very high

\subsection{Research Question 3:}

\section{What is the Level of Soft Skills Acquisition of the Students Who are Taking up the Malay Language?}

The analysis on the teachers' perception on the level of soft skills acquired by the students showed that communication skills scored the highest level $(m=3.52)$ compared to other soft skills. Interpersonal skills recorded second highest acquired with a mean value of 3.34 while environmental consciousness was rated as third highest skills acquired with a mean value of 3.27. This was followed by presentational skills $(m=3.26)$, decision making skills $(m=3.26)$, life-long learning $(m=3.10)$ and entrepreunership skills with the lowest score of 2.98. The overall mean showed in this domain was 3.24; a score depicting an average score for soft skills acquisition in the Malay language( Table 10). 
Teachers perception on their readiness in integrating soft skills in the teaching and learning

Table 10: Frequency Distribution, Percentage, Mean and Level of Students'Acquired Soft Skills in Malay Language

\begin{tabular}{|c|c|c|c|c|c|c|c|c|}
\hline Item & 1 & & 2 & 3 & 4 & 5 & Mean & Level \\
\hline \multirow[t]{2}{*}{ Communication } & [2] & {$[10]$} & [88] & [82] & {$[18]$} & 3.52 & Good & \\
\hline & $10.0 \%$ & $5.0 \%$ & $44.0 \%$ & $41.0 \%$ & $9.0 \%$ & & & \\
\hline \multirow[t]{2}{*}{ Team Work } & [1] & [17] & [84] & [78] & [20] & 3.50 & Good & \\
\hline & $0.5 \%$ & $8.5 \%$ & $42.0 \%$ & $39.0 \%$ & $10.0 \%$ & & & \\
\hline \multirow[t]{2}{*}{ Interpersonal } & [1] & [27] & [89] & [69] & [14] & 3.34 & Moderate & \\
\hline & $0.5 \%$ & $13.5 \%$ & $44.5 \%$ & $34.5 \%$ & $7.0 \%$ & & & \\
\hline \multirow{2}{*}{ Sensitivity In Environment } & [6] & [24] & [92] & [66] & {$[12]$} & 3.27 & Moderate & \\
\hline & $3.0 \%$ & $12.0 \%$ & $46.0 \%$ & $33.0 \%$ & $6.0 \%$ & & & \\
\hline \multirow[t]{2}{*}{ Presentation } & [3] & [37] & [79] & [67] & [14] & 3.26 & Moderate & \\
\hline & $1.5 \%$ & $18.5 \%$ & $39.5 \%$ & $33.5 \%$ & $7.0 \%$ & & & \\
\hline \multirow[t]{2}{*}{ Decision Making } & {$[0]$} & {$[32]$} & [95] & [63] & [10] & 3.26 & Moderate & \\
\hline & $0 \%$ & $16.0 \%$ & $47.5 \%$ & $31.5 \%$ & $5.0 \%$ & & & \\
\hline \multirow[t]{2}{*}{ Lifelong Learning } & [5] & [30] & [99] & [57] & [9] & 3.18 & Moderate & \\
\hline & $2.5 \%$ & $15.0 \%$ & $49.5 \%$ & $28.5 \%$ & $4.5 \%$ & & & \\
\hline \multirow[t]{2}{*}{ Problem Solving } & {$[4]$} & [24] & [111] & [56] & [5] & 3.17 & Moderate & \\
\hline & $2.0 \%$ & $12.0 \%$ & $55.5 \%$ & $28.0 \%$ & $2.5 \%$ & & & \\
\hline \multirow[t]{2}{*}{ Critical Thinking } & [3] & [48] & [99] & [43] & [7] & 3.02 & Moderate & \\
\hline & $1.5 \%$ & $24.0 \%$ & $49.5 \%$ & $21.5 \%$ & $3.5 \%$ & & & \\
\hline \multirow[t]{2}{*}{ Creative Thinking } & [3] & [39] & {$[101]$} & [49] & [8] & 3.10 & Moderate & \\
\hline & $1.5 \%$ & $19.5 \%$ & $50.5 \%$ & $24.5 \%$ & $4.0 \%$ & & & \\
\hline \multirow[t]{3}{*}{ Entrepreneurship } & {$[10]$} & [49] & [85] & [47] & [9] & 2.98 & Moderate & \\
\hline & $5.0 \%$ & $24.5 \%$ & $42.5 \%$ & $23.5 \%$ & $4.5 \%$ & & & \\
\hline & \multicolumn{6}{|c|}{ Total Mean } & 3.24 & Moderate \\
\hline
\end{tabular}

*indication : 1=very poor; $2=$ poorly; 3=moderate; 4=good ; 5=very good

*scaling soft skills mastery levels

mean $1.00-1.80$ : level - very poor

mean $1.81-2.60$ : level - poorly

mean $2.61-3.40$ : level - moderate

mean $3.41-4.20$ : level - good

mean 4.21 - 5.00 : level - very good

\section{Discussion}

The findings show that all the Malay language teachers from the 22 secondary schools have the soft skills and ability to impart the soft skills to their students in the teaching and learning process. The teachers are aware of the importance of soft skills for the students' future; as such they consider imparting such skills as crucial and not as an added burden to the teaching and learning process. The teachers also have agreed to attend training sessions and courses to upgrade their knowledge and comprehension of soft skills. This study also shows that the Malay language teachers who participated in this study have a high awareness on the need of soft skills. This is because most of the respondents agreed to the statement that soft skills are important to churn out students who will be more confident, successful and excellent. The teachers also agree to integrate soft skills in the teaching curriculum.

As for the application of soft skills in the Malay language teaching, the respondents are all aware of the assimilation of soft skills in the Malay language curriculum objectives. The teaching process also will be more interesting and effective if the soft skills are embedded systematically. In addition, the students' active participation in the teaching and learning process will subsequently leave a positive impact on the students themselves. Integrating the soft skill elements in the lesson will enable the students to be better prepared for the examinations and the real world and it will not deter their preparation for the examinations. However, there are some suggestions by the teachers to introduce specific activities to enhance soft skills acquisition of the students.

All the respondents in this study agree that the 11 sub-soft skills given in the questionnaire were given due emphasis in the teaching and learning of the Malay language. This is in line with the Malay language curriculum objectives which emphasizes soft skills in the reading and writing component of the Malay language. The communication skills is given the highest emphasis; followed by team work, interpersonal skills, critical 
thinking skills, life long learning skills, decision making skills, as well as presentational skills. Other skills that should be given emphasis include problem solving skills, environmental awareness skill and finally the entrepreneurship skills.

From the aspect of acquiring soft skills via the Malay language, it is noted that the students' level of acquirement is considerably moderate. Only communication skills and team work showed a high level of acquirement. The level of acquirement for other sub-soft skills such as critical thinking skills, creative thinking, decision making, team work, interpersonal, life long learning, presentational, entrepreneurship and environmental awareness is considerably moderate. The teachers also rated these two skills as having the highest level of achievement. Although entrepreneurship skill is also given due emphasis in the teaching of Malay Language, yet it is rated as the lowest when compared to the other soft skills.

\section{Conclusions}

It is highly recommended that soft skills acquisition is pertinent for students; as such the teachers should be given a more comprehensive training and course to instill the soft skills acquisition more effectively in the teaching and learning process. Such training and courses on the other hand must integrate detailed content, skills specification, evaluation as well as teaching and learning activities that need to be acquired. The knowledge of soft skills itself is highly important for the teachers to diversify the teaching strategies for the students. This effort however, should begin in the training of pre-service teachers either in the teacher training institutes or the universities. This calls for the planning of a specific curriculum that can be integrated in the teacher training and university curriculum. At the same time, the students also should be exposed to the method of acquiring soft skills. As the process becomes a two way process, the teaching and learning process will become more systematic and effective as posited by Adediwura and Bada (2007) that effective teaching and learning of the soft skills are also reliant on the knowledge, skills and the attitude of the teachers.

In allowing a more comprehensive acquisition of soft skills among the students, the teachers also need to have a more commited and pragmatic approach. This would then address the issue of moderate acquisition of soft skills among students. The teaching of soft skills should not be carried out in isolation but should be assimilated into the teaching and learning process. However, there is a need to ensure effective activities are carried out to consolidate the soft skills learning. In short, the planning of the learning activities should be based on two objectives; firstly to achieve the target lessons' aims and secondly to ensure the stipulated soft skills elements, such as team work are also achieved. Constant reminders on the importance of the soft skills for the future generation should be embedded during the teaching and learning process.

At the Ministry level, there is a need to plan and develop specific soft skills that will be applicable for all schools. For example, among the other soft skills that are applicable for the Malay Language subject include communication skills (both written and spoken), team work, critical and creative skills as well as decision making skills. Yet, this skill may be reviewed based on the school environment and culture. As such, the school Curriculum Panel can formulate the needed soft skills to suit their needs according to the objectives stipulated for the lessons. The school management also can identify or select certain niche areas and focus on the various soft skills needed for their students. For example, if a school gives emphasis on school beautification project and environmental awareness, then these elements should be emphasized in the soft skill elements within the lesson.

The study is pertinent to elicit information on the knowledge and understanding of soft skills amongst teachers and contribute constructive feedback for further actions to be taken by the Malaysian Higher Learning Ministry, teacher training institutions and education faculties in various public and private higher learning institutions. A more systematic and effective planning will be feasible to equip the pre-service teachers with soft skills knowledge. With the adequate knowledge on soft skill, the teachers too will be able to plan and design the relevant teaching and learning activities to instil soft skills among students. The integration of soft skills among students is a new and commendable effort. The awareness of the importance of soft skills and the formal integration amongst students needs to be accelerated. This study, as such aims to enlighten fundamental information and pertinent need for soft skills to be integrated in schools. As there are limited studies carried out on soft skills integration amongst school students, this study serves to provide a guideline to the relevant stakeholders to implement relevant programmes to empower students with soft skills. However, there is a need to carry out a more comprehensive nationwide study to gauge the teachers knowledge, comprehension and readiness to implement soft skills at national level.

\section{Acknowledgement}

research.

I would like to express my sincere gratitude to Universiti Sains Malaysia for granting the Incentive Grant to complete this 


\section{References}

[1] Erik, R. \& Piet, S. (2007), Towards a framework for assessing teacher competence. European Journal of Vocational, Training 40(1), $123-139$

[2] Malaysian Higher Learning Institution, (2006). Modul Pembangunan Kemahiran Insaniah (soft skills) untuk Institusi Pengajian Tinggi Malaysa. Malaysia: Penerbit Universiti Putra Malaysia.

[3] Boyatzis, R. E. (1982). The competent manager: A model for effective performance. In Arnold, J., Loan-Clarke, J., Harrington, A. \& Hart, C. (Eds). Students perception of competence development in undergraduate business-related degrees. Studies in Higher Education, 24(1), $43-59$

[4] Brown, R. B. (1994). Reframing the competence debate. In Arnold, J, Loan-Clarke, J, Harrington. A \& Hart. C. Students perception of competence development In undergraduate business-related degrees. Studies in Higher Education, $24(1), 43$ - 59.

[5] Otter, S., (1995). Assessing competence - The experience of the enterprise in higher education initiative. In Edwards, A. \& Knight, P. (Eds.). Assessing competence inhigher education. London: Kogan Page Limited.

[6] Spencer, L. M. \& Signe, S. M. (1993). Competence at work: Models for superior performance. US: John Wiley \& Sons, Inc.

[7] Lucia, D., \& Lepsinger, R. (1999). The art and science of competency models: Pinpointing critical success factors in organizations. San Francisco: Jossey-Bass/Pfeiffler.

[8] Judith, F. \& Tom, J. (1999) Key aspects of teaching and learning in business and management studies. In Heather, F., Steve, K., Stephanie, M. (Eds.). A Handbook For Teaching and Learning in Higher Education - Enhancing Academic Practice. London: Kogan Page.

[9] Candy, P. C. \& Crebert, R. G. (1991). Ivory tower to concrete jungle:The difficult transition from the academy to the workplace as learning environments. Journal of Higher Education, 62(5), 570 - 592.

[10] Hodgkinson, (1998). A rationale for an introduction of Lifelong Learning Skills: Business, management and accounting undergraduate awards. Journal of Further and Higher Education, 22(2), 151 - 162.

[11] Hyland, T., \& Johnson, S. (1998). Of cabbages and key skills: Exploding the mythology of core transferable skills in post school education. Journal of Further and Higher Education, 22(2), 163 - 172

[12] Apple, W. (1998). Work, power and curriculum reform: A response to Theodore Lewis's vocational education as general education. Curriculum Inquiry, 28(3), $339-360$.

[13] Knight, T. \& Yorke, M. (2001). Employability through the curriculum. Paper presented at the EAIR Forum, Porto, Portugal Retreived from http://www.open.ac.uk/vqportal/Skill- Plus/home.htm

[14] Knight, T. (2002). Innovation in education for employbility. Paper presented at the Skill Plus Conference. Center for OutcomesBased Education, The Open University Retreived from http://www.open.ac.uk/vqportal/Skill-Plus/home.htm

[15] Gregory, J., Kelly, A. L. \& Judith, G. (2008), Knowledge, Assessment, and Curriculum What Counts as Knowledge in Educational Settings: Disciplinary. Research and Review, 32, vii-x. American Educational Research Education

[16] James, G. L. (2010). Beyond Academic Outcomes. Review of Research in Education, 34,113 - 140. Retreived from http://www.sagepublications.com

[17] Tom, A. R.\& Valli, L. (1990). Professional knowledge for teachers. In Houston R. W. (Ed.). Handbook of research on teacher education. NY: MacMillan, $372-392$

[18] Kagan, D. M. (1990). Ways of evaluating teacher cognition: Inferences concerning the Goldilocks principle. Review of Educational Research, 60(3), $419-469$.

[19] Beijaard, D. \& Verloop, N. (1996). Assessing teachers' practical knowledge. Studies in Educational Evaluation, 22(3), 275 - 286.

[20] Barrie, C. B. (2007), A conceptual framework for the teaching and learning og generic graduate attributes. Studies in Higher Education, 32(4), $439-458$.

[21] Omar, O. (2005). Skills and Competencies in the workplace - An overview of current problems and the balancing role for higher education in Malaysia. Paper presented at the National Conference on Skill \& Competencies in Education, Universiti Sains Malaysia.

[22] Adediwura, A. A. \& Bada, Tayo, (2007).Perception of teachers' knowledge, attitude and teaching skills as predictor of academic performance in Nigerian secondary schools educational. Research and Review, 2(7), 165 - 171,

[23] Eggen P, \& Kauchak, D. (2002). Strategies for teachers: Teaching content and thinking skills (4th ed.). Needham Heights: M.A. Allyn and Bacon. 